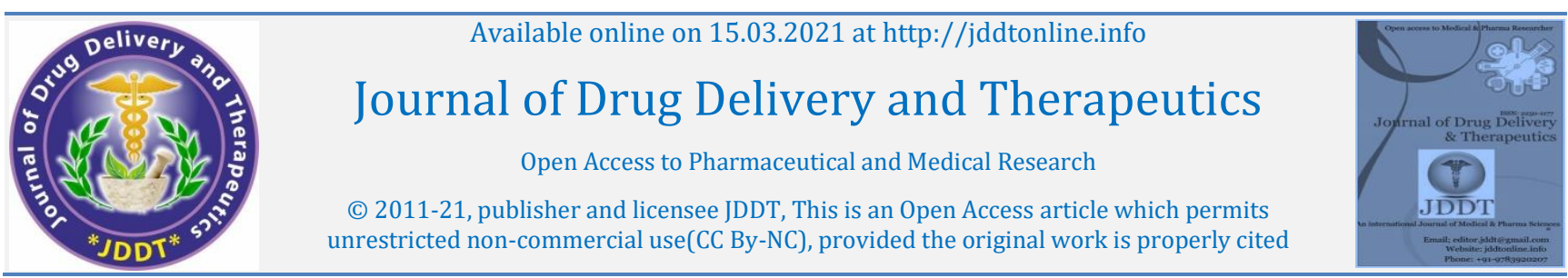

\title{
A Review on Natural Plants for Phytochemical Constituents and Pharmacological Activities
}

\author{
Muni Raja Lakshmi. $K^{*}$, M. Kiran, K. Sai Prasanna \\ SVU College of Pharmaceutical Sciences, SV University, Tirupati - 517501, Andhra Pradesh, India
}

\begin{tabular}{ll}
\hline Article Info: & \\
\hline ⿴囗口 & Article History: \\
& Received 03 Jan 2021; \\
Accew Completed 21 Feb 2021 \\
Available online 2021; 15 March 2021
\end{tabular}

Cite this article as:

Lakshmi K MR, Kiran M, Sai Prasanna K, A Review on Natural Plants for Phytochemical Constituents and Pharmacological Activities, Journal of Drug Delivery and Therapeutics. 2021; 11(2):232-236 DOI: http://dx.doi.org/10.22270/jddt.v11i2.4593

\author{
*Address for Correspondence: \\ Muni Raja Lakshmi. K, SVU College of \\ Pharmaceutical Sciences, SV University, Tirupati - \\ 517501, Andhra Pradesh, India
}

\begin{abstract}
The present review aims for the study of phytoconstituents and pharmacological activities of some natural plants. The traditional medicinal plants have been found to acquire therapeutic activities significantly antimicrobial, anti-inflammatory antibacterial, anti-fungal, antioxidant properties etc. The plant-derived constituents are majorly for the aliments of used skin disease diabetes, bronchitis, asthma, arthritis, dry cough, ulcer and fever. The antimicrobial activity of the following plants like Justicia adathoda, Lantana Camara, Acacia leucophloea, Holoptelea integrifolia, Calotropis Procera, chlorophytum tuberosum, Bombax ceiba, Bacopa monnieri, Wedelia trilobata, Jatropha gossypifolia were obtained from the extraction of either leaves, stem or flowers by using ethanol, methanol, aqueous, petroleum ether, chloroform. The phytochemical constituents of the extract have been shown the presence of alkaloids, glycosides, cardiac glucosides tannins, proteins, carbohydrates, saponin, quinines, triterpenes, steroids, polyphenolic, volatile oil, phenols, starch sugar, amino acid, resin and organic acids. This study evidenced the possible use of the mentioned plants as a source of natural medicines which are used as an antimicrobial, anti-inflammatory, anti-bacterial, antifungal, antioxidant agents.
\end{abstract}

Keywords: Medicinal plants, Antimicrobial, Anti-inflammatory, Antioxidants.

\section{INTRODUCTION:}

Medicinal plants have played a critical role in maintaining human health and quality of human life for thousands of years. The use of plants as medicines is as old as human civilization itself and out of about species of higher plants reported from the world. Presently about $70 \%$ of the world population use herbal medicines, mainly in developing countries for primary health care because of better cultural acceptability of the human body. Many of existing medicinal systems such as Ayurveda, Unani, homoeopathy, naturopathy, Siddha and other alternative medicinal system have been utilizing plants as an effective medicine to cure many harmful diseases. ${ }^{1}$

The world health organization (WHO) has estimated that $80 \%$ of the earth's inhabitants relied on traditional medicine for their primary health care needs and most of these therapies involved the use of plant extract of the active compounds. The number of multi-drug resistant microbial strains and the appearance of strains with reduced susceptibility to antibiotics is continuously increasing. This increase has been attributed to indiscriminate use of broadspectrum antibiotics, immunosuppressive agent, intravenous catheters, organ transplantation and on-going epidemics of HIV infections. Therefore it is a need to search for new infection-fighting strategies to control microbial infections. The anti-microbial activity of some medicinal plants used in Ayurveda and traditional medicinal system for treatment of manifestations caused by microorganisms. Therefore extracts of the few plants from different families were studied for their potential activity against microbial pathogens. Plants like Justicia adathoda, Lantana Camara, acacia leucophloea, holoptelea integrifolia, calotropis procera, chlorophytum tuberosum, bombax ceiba, bacopa monnieri, wedelia trilobata, jatropha gossypifolia. Were studied for their anti-microbial and other potential pharmacological activities. $^{2}$

The phytochemical constituents which possess activities like anti-bacterial, anti-fungal, anti-inflammatory, anti-oxidant, abortifacient, anti-cholinesterase, anti-tubular activity. Were studied plants containing in the present review of phytochemical constituents like Alkaloids, glycosides, steroidal, triterpenes, flavonoids, polysaccharides, proteins, uronic acids, essential oils having anti-tussive, wound healing and anti-microbial activity like growth inhibition. zone appearing as a clear area around the source agent test on Gram-positive bacteria and gram-negative bacteria of Staphylococcus aureus, Bacillus subtilis, Pseudomonas aeruginosa, Proteus Vulgaris, aspergillus Niger, aspergillus flavus, fusarium oxyspotum, E.coli, and Penicillium digitatum. ${ }^{3}$

The total plant part of Justicia adhatoda has been used in ayurvedic system of medicine for the treatment of various ailments of the respiratory tract in both children and adults. Various parts of the plant are used in Indian traditional medicines for the treatment of asthma, joint pain, lumbar pain, sprains, cold, cough, eczema, malaria, rheumatism, 
swelling and venereal disease. The fluid extract and tincture were used as an antispasmodic, expectorant and febrifuge. Plants having Anti-microbial activity, anti-bacterial activity, anti-fungal, anti-oxidant, analgesic, anti-inflammatory activity, anti-diabetic, anti-cancer, anti-tussive, antitubercular, wound healing activity, hepatoprotective activity, CNS depressants, hypolipidemic activities were chosen to their review. 4

\section{BIOLOGICAL SOURCE, PHYTOCHEMICAL CONSTITUENTS AND PHARMACOLOGICAL ACTIVITIES:}

1. Justicia adathoda belongs to family Acanthaceae, is a diffuse shrub, growing throughout the Indian peninsula. This plant has been used commonly in the ayurvedic system of medicine. The leaf is simple, entire, wavy, ovate, lanceolate, apex acuminate 6 to $14 \mathrm{~cm}$ long, 3 to $5.5 \mathrm{~cm}$ broad, and midrib prominent of the lower surface area. The leaf powder was dark green in colour, bitter in taste. The extract of Justicia adathoda could from one of the best options for developing novel natural medicine. The anti-microbial activity of leaf extracts of Justicia adathoda was done to Alkaloids, glycosides, cardiac glycosides, steroidal, triterpenes, resin and saponin which were present in the aqueous and ethanol extract. The isolated phytochemical constituents of Justicia adathoda possesses anti-microbial, anti-fungal, antibacterial, anti-inflammatory, anti-tussive, anti-tubular activity, respiratory disorders, asthma, and bronchodilator activity. Anti-microbial activity of methanol and leaf extracts of Justicia adathoda was tested on Staphylococcus aureus, bacillus subtilis, pseudomonas aeruginosa and Penicillium digitatum by the disc diffusion method. The effectiveness of particular anti-microbial agent results in the production of the growth inhibition zone appearing as a clear area around the source agent. ${ }^{5}$

2. Lantana Camara belongs to family Verbenaceae found in tropical and sub-tropical areas. Lantana Camara is a medium-sized perennial aromatic shrub, 2-5 m tall, with quadrangular stems, sometimes having prickles. The leaves are generally oval or broadly lance-shaped, $2-12 \mathrm{~cm}$ in length and 2-6 $\mathrm{cm}$ broad having a rough surface and a yellow-green to green colour. The antibacterial activity of the leaves and roots extracts of Lantana Camara ethanol extracts of phytochemical analysis shows the presence of quinines, alkaloids, terpenes, flavonoids. These plants are used as antipyretic and carminative and in the treatment of respiratory system infections, skin disease. The antibacterial activity of the ethanol extracts of Lantana Camara leaves and roots have antibacterial activity against gram-positive and gram-negative strains standard and multi-resistant bacteria isolated from Pseudomonas aeruginosa and multi-resistant of Escherichia coli with possesses activities shown that gram-positive bacteria are more sensitive to antibiotics. The gram-negative bacteria display some particularities that inhibit antibiotics penetration, as the lipopolysaccharide layer that determines the permeability and susceptibility to antibiotics. 6

3. Acacia leucophloea is a member of the family Mimosaceae. This tree grows about $25 \mathrm{~m}$ seen in deciduous forests, nearly white bark with pale brown Inner side, leaves bipinnate, compound leaves 3-4 cm long, glabrous, leaflets are oblong and obtuse, flower large terminal tomentose panicles, fruits pod, sessile, thin and flat, seeds 10-16 per pod. The aerial parts extract of acacia species was isolated from the ethanol and chloroform extract of the plants possess anti-microbial activities due to the presence of flavonoids and polyphenolic, glycosides, volatile oil, amino acids, organic acids. Acacia species are used in folk medicine by people in rural areas as a remedy for tuberculosis, leprosy, smallpox, cough, skin ulcers, and toothache. The isolated bacteria against ethanol extract was higher than chloroform extract used in similar concentrations especially Staphylococcus aureus, Escherichia coli, Klebsiella pneumoniae, Proteus Vulgaris and pseudomonas aeruginosa. The ethanol extract at concentrations of 13 and $6.7 \%$ and chloroform extract at $13 \%$ showed the largest inhibition zones when compared with other test antibiotics. ${ }^{7}$

4. Holoptelea integrifolia belongs to family Ulmaceae. It is a medium-sized tree growing to a height of 10-15 m. The bark is pale white-coloured. Leaves are 3-5 inch long, 2-3 inch wide, oval to renal shaped. The flowers are small, greenishyellow and found in clusters. The fruits are round and the seeds are flat. Both flowers and fruits release a pungent odour when crushed. The ethanol extracts of leaves have anti-bacterial activities due to the presence of phytochemical constituents such as terpenoids, sterols, saponins, tannins, proteins, carbohydrates, alkaloids, phenols, flavonoids, glycosides, and tannins. The isolated crude extracts show antibacterial, anti-fungal, anti-inflammatory, and analgesic, anti-diabetic wound healing activities. It is used in the treatment and prevention of several ailments like leprosy, inflammation, rickets, rheumatism, ringworm, eczema, malaria, intestinal cancer, chronic wounds. The biological studies such as antimicrobial, antihelminthic, antidiabetic, anti-inflammatory, and antioxidant activities were noticeable in crude extracts of various parts of the plant. Holoptelea integrifolia may be used as an effective therapeutic remedy in the prevention and treatment of various ailments. ${ }^{8}$

5. Calotropis procera belongs to family Asclepiadaceae. Calotropis procera is a spreading shrub or medium-sized tree reaching 2.5 to $6 \mathrm{~m}$ in height. It has a deep taproot 3-4 m deep and a secondary root system with woody lateral roots that may rapidly regenerate adventitious shoots when the plant is injured. The stems are crooked and covered with a fissured corky bark. The fruit is a fleshy and inflated, up to 10 $\mathrm{cm}$ or more in diameter. The grey-green leaves are $15-30 \mathrm{~cm}$ long and $2.5-10 \mathrm{~cm}$ broad and have a succulent and waxy appearance, hence the name procera, which means wax in Latin. The ethanol and aqueous extract of the leaves and flowers consist of flavonoids and glycosides as the bioactive constituents. It was used in the treatment of asthma, skin, digestive, respiratory, fever, nausea, vomiting, diarrhoea, cancer and anti-diabetic. The ethanolic leaf extracts of Calotropis procera was anti-microbial activity agents Escherichia coli, Staphylococcus aureus, Staphylococcus albus, Streptococcus pyogenes, Streptococcus pneumoniae and Aspergillus niger. The ethanolic extracts of Calotropis procera latex gave the widest zone of inhibition $(14.1 \mathrm{~mm})$ against E-coli using agar well diffusion while $9.0 \mathrm{~mm}$ was recorded for the same organism in the disc plate method. ${ }^{9}$

6. Chlorophytum tuberosum is an Asparagus family. Leaves 15-25 and 1-1.5 cm, ensiform, sheathing at base. Scape 25-35 $\mathrm{cm}$, flowers towards the tip of the spike, racemose. Bracts 1-3 $\mathrm{cm}$ long, lanceolate. Flowers white, 2-2.5 cm across. Ovule 4 or more in each cell, stigma simple. Capsule 1-1.5 and 0.8-1 $\mathrm{cm}$, oblong, triquetrous. Seeds $0.3-0.35 \mathrm{~cm}$ long irregularly pitted. The anti-microbial activity of aqueous extract of leaves of the preliminary phytochemical screening of leaves reveals the presence of starch, proteins, sugars, tannins, flavonoids, alkaloids and mucilage. Chlorophytum tuberosum is used in the treatment of diarrhoea, dysentery, demulcent, and galactagogue. The anti-microbial activities agents such as Escherichia coli, bacillus subtitles and Aspergillus Niger and C.albicans as the mention of Chlorophytum tuberosum show excellent activity against bacteria as well as fungi. ${ }^{10}$ 
7. Bombax ceiba belonging to family Bombacaceae is commonly known as salami. A large tree, up to $40 \mathrm{~m}$ height by $2 \mathrm{~m}$ in diameter. The stem is buttressed at the base. Silk cotton tree is a type of native cotton tree with large red flowers. It is traditionally used in Ayurveda. Anti-bacterial activity of aqueous extracts of a steam bark is due to the presence of flavonoids, glycosides, sterol, and terpenoids. Bombax ceiba has used as acrid, demulcent, diuretic, inflammation, swelling, boil and burning sensation. The activity against six medically important bacterial strains, namely Gram-positive Bacteria Bacillus subtilis, Bacillus aureus and Staphylococcus aureus and Gram-negative bacteria Escherichia coli, Klebsiella pneumoniae, and Pseudomonas aeruginosa. The aqueous extract was more significant against Gram-positive bacteria than against Gramnegative bacteria. The $100 \mu \mathrm{g} / \mathrm{ml}$ showed the best antibacterial activity as compared to the standard. ${ }^{11}$

8. Bacopa monnieri Linn family Scrophulariaceae. Bacopa monnieri is a non-aromatic herb. The leaves of this plant are succulent, oblong, and 4-6 mm (0.16-0.24 in) thick. Leaves are oblanceolate and are arranged oppositely on the stem. The flowers are small, actinomorphic and white, with four to five petals. Its ability to grow in water makes it a popular aquarium plant. The anti-microbial activity of the ethanol extract of aerial parts of Bacopa monnieri is due to the presence of phytochemical constituents of tetracyclic triterpenoid, saponins, bacosides A and B, saponin, alkaloids, herpes tine, and Brahmin and some flavonoids. Bacopa monnieri Linn in the treatment of insanity, epilepsy, and asthma and skin disease. Ciprofloxacin $(5 \mu \mathrm{g} / \mathrm{ml})$ and Clotrimazole $(25 \mu \mathrm{g} / \mathrm{ml})$ were used as Minimum inhibitory concentration of the extract by broth dilution method and agar disc diffusion method. The zone of inhibition was studied by at concentrations of 2, 5 and $10 \mathrm{mg} / \mathrm{ml}$ in DMSO. The better effectiveness against gram-positive bacteria than gram-negative bacteria. ${ }^{12}$

9. Wedelia trilobata belongs to family Asteraceae. Wedelia trilobata is perennial and grows to $45-60 \mathrm{~cm}$ high. Stems are green, rounded, rooting at nodes, $10-30 \mathrm{~cm}$ long, and the flowering portions ascending, coarsely strigose to spreading hirsute, sometimes subglabrous. Leaves are medium textured, fleshy, usually 4-9 cm long (1.5-) 2-5 cm wide, simple obovate, irregularly toothed or serrate, usually with a pair of lateral lobes. Flowers, solitary, arise in the leaf axils at any height but appear to have the most blossoms at about $10 \mathrm{~cm}$ above ground level. Anti-microbial, anti-oxidant and anti-inflammatory activity of dry and fresh parts of leaf, stem, and flower from the water extract of wedelia trilobata has phytochemical constituents of tannins, cardiac glycosides, flavonoids, terpenoids, phenols, saponins, and coumarins. The fresh parts water extracts showed that leaf and flower extracts were most potent inhibiting all isolates of with different zones of inhibition of the growth of fungi tested. It is a phytochemical present in the wedelia trilobata extract may be responsible and can be used as an antimicrobial, antioxidant and anti-inflammatory agent. It is mainly used in the treatment of reproductive problems, amenorrheas, chest cold, dry cough, and fever. ${ }^{13}$

10. Jatropha gossypifolia is a Euphorbiaceae family. Shrubs, purplish-green and glandular-hairy on younger parts. Leaves in a close spiral, deeply 3-5-lobed, 7-12 cm, petiole $3-10 \mathrm{~cm}$ long, glandular-hairy. Flowers red with yellow centre, unisexual in axillary and terminal monoecious corymbose cymes. Bracts linear-lanceolate, glandular-hairy. Antimicrobial and anti-bacterial activities of ethanol extract of the leaves are due to phytochemical compounds including tannins, flavonoids, saponins, steroids, and triterpenoids. It is used as traditional medicine for the various ailments in asthma, arthritis, washing wounds, blood purifier, bronchitis, diarrhoea, dysentery, fever, gum infection, leprosy, stomach, ulcer and anti-inflammatory. Antibacterial activity against such as Escherichia coli, Proteus Vulgaris, Staphylococcus aureus and Bacillus cereus and Trichophyton macrophytes by the disc diffusion method. ${ }^{14}$

\section{EXTRACTION PROCEDURE:}

\section{Justicia Adathoda:}

Five hundred grams of coarse powder of shade dried leaves of Justicia adhatoda was extracted successively with petroleum ether $\left(60-80^{\circ} \mathrm{C}\right)$, chloroform, ethyl acetate and methanol in a soxhlet extractor for $48 \mathrm{~h}$. dark green residues were obtained after concentrating the extract under reduced pressure (Yield $8.20 \%, 3.80 \%, 2.15 \%$ and $14.30 \%$ respectively). The obtained extracts were stored in desiccators for further phytochemical and antimicrobial investigations. The dried material was tested for its constituents by standard methods. The plant extracts were diluted with respective solvents to the final concentration of $20 \mathrm{mg} / \mathrm{ml}$. Microorganisms like Escherichia coli, Klebsiella pneumonia, Staphylococcus aureus, Pseudomonas aeruginosa, Proteus Vulgaris and Candida albicans were used for the evaluation of their given extraction procedure for the above-mentioned plants in their order. ${ }^{15}$

\section{Lantana Camara:}

Ethanol extracts were prepared using the cold extraction method. Lantana Camara (240 g of the fresh leaves and $185 \mathrm{~g}$ of the roots) were placed in a flask containing cold ethanol and left in this position for $72 \mathrm{~h}$ at ambient temperature. A rotary vacuum pump extractor was used to remove the ethanol from the extracts (under reduced pressure). The extracts presented an antibacterial activity against clinically relevant pathogens (gram-positive and gram-negative). Lantana Camara leaves extract was active against proteus vulgaris and V. cholerae (MIC $128 \mu \mathrm{g} / \mathrm{mL}$ for both strains) in addition the root extract was effective against proteus vulgaris and Pseudomonas aeruginosa (64 and $128 \mu \mathrm{g} / \mathrm{mL}$, respectively) the extracts were weighed and stored. 16

\section{Acacia Leucophloea:}

The Acacia leucophloea was studied on crud extract of bark, leaves with $80 \%$ ethanol $(100 \mathrm{ml} / \mathrm{gm} \mathrm{dry} \mathrm{weight})$ on a water bath for $24 \mathrm{hrs}$ using soxhlet apparatus. The solvent was evaporated using a rotary vacuum-evaporator at $50{ }^{\circ} \mathrm{C}$. The anti-bacterial activity against of Lactobacillus acidophilus, Streptococcus sanguinis, Streptococcus salivarrius, Aggregatibacter using agar diffusion technique and determine the minimum inhibitory concentration of each extract against dental pathogen. ${ }^{17}$

\section{Calotropis Procera:}

The antimicrobial activity of ethanol, aqueous and chloroform extracts of leaf and latex of Calotropis procera.The leaf powder and the latex (10g each) were dissolved in $100 \mathrm{ml}$ of each solvent. The suspended solutions were left to stand for 5 days and labelled accordingly on six bacterias namely, Escherichia coli, Staphylococcus aureus, Staphylococcus albus, Streptococcus pyogenes, Streptococcus pneumonia. The extracts were filtered and stored at $4^{0} \mathrm{c} .18$

\section{Chlorophytum Tuberosum:}

The chlorophytum tuberosum was studied on aqueous extracts of leaves collected the dried powder and shaded powder separately. Leaves are macerate in water for 24 hours and dried by evaporation in vacuum. Dried extracts 
are stored at $4^{\circ} \mathrm{C}$ airtight containers for further study. Aqueous extracts of phytochemicals constituents such as starch, proteins, sugars, tannins, flavonoids, alkaloids and mucilage. The anti-microbial activity agents like Staphylococcus aureus, Escherichia coli, Bacillus substilis, Proteus vulgaris and Aspergillus niger, C. Albicans. All the fresh cultures of microorganisms are prepared in nutrient broth and are incubated for 24 hours at $37^{\circ} \mathrm{c} . .^{19}$

\section{Bombax Ceiba:}

The antibacterial activity of aqueous extracts of the bark of Bombax ceiba. The bark of Bombax ceiba was dried at room temperature $\left(25-35^{\circ} \mathrm{C}\right)$ and prepared the powdered with the help of an electric grinder. The coarse material was macerated with distilled water and $10 \%$ of chloroform and keep for 7days. After seven days filter through a muslin cloth and filtrate transfer in evaporating dish and keep on $50^{\circ} \mathrm{C}$ in a water bath. The percentage yields obtained from the extracts was $21.20 \%$. Aqueous extracts of Bombax ceiba was prepared by sterile distilled water $(1 \mathrm{mg} / \mathrm{ml})$. Further test dilutions were made ranging from $10 \mu \mathrm{g} / \mathrm{ml}$ to $100 \mu \mathrm{g} / \mathrm{ml}$ by sterile distilled water. The bacterial suspension was prepared by transferring a loopful of inoculum into $1 \mathrm{ml}$ sterile saline solution from the stock culture maintained at $4^{\circ} \mathrm{C}$ in $10 \mathrm{ml}$ nutrient broth. ${ }^{20}$

\section{Bacopa monnieri Linn:}

The antimicrobial study on aerial parts of Bacopa monnieri petroleum ether and ethanol extract by the powdered plant using soxhlet apparatus. The solvent was removed under reduced pressure, which gave a greenish-black coloured. The dried extract was mixed with dimethyl sulfoxide (DMSO) for antimicrobial study. Preliminary phytochemical screening of the extract gives positive for the presence of saponins, flavonoids and alkaloids. The microorganisms agents such as Staphylococcus aureus, Bacillus subtilis, Bacillus polymyxin, Streptococcus faecalis, Pseudomonas aeruginous, Salmonella typhi, Vibrio cholerae, Shigella dysenteriae, Escherichia coli, Penicillium notatum and Aspergillus niger respectively. ${ }^{21}$

\section{Wedelia Trilobata:}

The antimicrobial study on leaves aqueous extract of wedelia trilobata dried at room temperature. Then $100 \mathrm{~g}$ of wedelia trilobata leaves was distilled in water sign an allglass Clevenger-type apparatus $(n=3)$. The obtained essential oil was dried over anhydrous $\mathrm{Na}_{2} \mathrm{So}_{4}$ and measured for calculation of percentage yield. The oil was stored in an amber vial at $4{ }^{\circ} \mathrm{C}$ until analysis. ${ }^{22}$

\section{Jatropha Gossypifolia:}

The Antimicrobial study on leaves of Jatropha Gossypifolia was use petroleum ether, chloroform, and alcohol extracts. About $50 \mathrm{~g}$ of powdered material was extracted in a soxhlet extraction apparatus with $250 \mathrm{ml}$ of solvents. The extracts obtained with each solvent were filtered through Whatman filter paper No. 1 and the respected solvents were evaporated (at $40^{\circ} \mathrm{C}$ ) with the help of heating mantle. The sticky greenish-brown substances were obtained and stored in a refrigerator prior to use. Some of the extracts of each solvent were used for the qualitative phytochemical constituents like tannins, lignin, starch grains and saponins. The positive tests are present $(+)$ and negative tests are absent $(-) .23$

\section{PHARMACOLOGICAL ACTIVITIES:}

\section{- Antibacterial activity:}

The antibacterial activity study on aqueous, methanol, acetone, diethyl ether, chloroform and hexane seeds extracts of Bombax Ceiba. It was determined using 2\% nutrient agar medium by the disc diffusion method. Microbial cultures are used for the study like Escherichia coli, Bacillus Subtilis, Staphylococcus aureus, Enterococcus faecalis and Alcaligenes faecalis. Minimum Inhibitory Concentration (MIC) was determined using different solvents extracts of concentration $50 \mu \mathrm{l}, 100 \mu \mathrm{l}, 150 \mu \mathrm{l}$ and $200 \mu \mathrm{l}$ to the wells incubating at $37^{\circ} \mathrm{C}$ for $24 \mathrm{hrs}$. The zone of inhibition was measured in millimetres ( $\mathrm{mm}$ ) compared against Amoxicillin (1ppm), a standard antibiotic. ${ }^{24}$

\section{- Anti-fungal activity:}

The antifungal activity study on petroleum ether, ethyl acetate, chloroform, methanol leaves extracts of Justicia adhatoda. The fungal activity against Proteus Vulgaris and Candida albicans by disc-diffusion method Ketoconazole (10mg disc-1) was used as standard. The filter paper disc impregnated with plant extract of $20 \mathrm{mg}$ individually and ketoconazole disc were placed aseptically on the seeded sabouraud dextrose agar medium which was already swabbed with the test organism and incubated at $37^{\circ} \mathrm{C}$ for $48 \mathrm{hr}$. The zone of inhibition in millimetres $(\mathrm{mm})$ was measured. 25

\section{- Antimicrobial Activity:}

Antimicrobial activities were studied on leaves ethanolic extract of Justicia adhatoda were carried out using the disc diffusion method. Petri plates were prepared with $20 \mathrm{ml}$ of sterile Mueller hinton agar(MHA).The test culture was swabbed on top of solidified media and allowed to dry for $10 \mathrm{~min}$ and a specific amount of the compound was added to each disc. The loaded dsics were placed on the surface of the medium and left for $30 \mathrm{~min}$ at room temperature for compound diffusion. Streptomycin was used as positive control for bacteria and ketoconazole as positive control for fungi. The plants were incubated for $24 \mathrm{hr}$ at $37^{\circ} \mathrm{C}$ for bacteria and for $48 \mathrm{hr}$ at $28^{\circ} \mathrm{c}$ for fungi.

Determination of Minimum inhibitory concentration (MIC):

Minimum Inhibitory Concentration (MIC) of the and ketoconazole extract was performed by broth dilution method at concentrations of the extract ranging from $25 \mu \mathrm{g} / \mathrm{ml}$ to $500 \mu \mathrm{g} / \mathrm{ml}$ in DMSO against Staphylococcus aureus, Bacillus subtilis, Bacillus polymyxin, Streptococcus faecalis, all this test microorganisms. ${ }^{26}$

\section{- Anti-inflammatory activity:}

Antimicrobial study on leaves aqueous extract of wedelia trilobata The reaction mixture was consisting of $1 \%$ aqueous solution of bovine albumin fraction, $\mathrm{pH}$ of the reaction mixture was adjusted using a small amount at $37^{\circ} \mathrm{C} \mathrm{HCl}$. The sample extracts were incubated at $37^{\circ} \mathrm{C}$ for $20 \mathrm{~min}$ and then heated to $51^{\circ} \mathrm{C}$ for $20 \mathrm{~min}$ after cooling the samples the turbidity was measured spectrophotometrically at $660 \mathrm{~nm}$. The experiment was performed in triplicate. Inhibition of protein denaturation was reported.27

\section{- Anti-oxidant activity:}

The anti-oxidant study on aqueous and methanol leaf extract of Adhatoda vasica Nees. The Diphenyl picryl hydroxyl (DPPH) stable free radical scavenging activity was determined by the method of Blois. Justicia adathoda leaf extract $3 \mathrm{ml}$ was added to $1 \mathrm{ml}$ of $0.1 \mathrm{~mm}$ solution of DPPH in methanol. After $30 \mathrm{~min}$ incubation at $37^{\circ} \mathrm{C}$ absorbance was measure at $517 \mathrm{~nm}$ against the control using a spectrophotometer. The total phenolics and flavonoids and ascorbic acid were determined along with antioxidant enzymes. Ascorbic acid and Butylated hydroxytoluene (BHT) 
are used materials. The inhibition percentage was calculated to the radical scavenging activity. ${ }^{28}$

\section{CONCLUSION:}

Traditional medicines (Ayurveda, Unani, Siddha), as natural therapeutics remedies have been used in all over the world for thousands of years and it is widely accepted that multiple constituents are responsible for their efficacy. The literature survey revealed that above-mentioned plants like Justicia adathoda, Lantana Camara, acacia leucophloea, holoptelea integrifolia, calotropis procera, chlorophytum tuberosum, bombax ceiba, bacopa monnieri, wedelia trilobata, jatropha gossypifolia has been widely studied for its phytochemical activities. These plants have phytochemical constituents like Alkaloids, glycosides, cardiac glucosides, steroidal, triterpenes, resin, saponin, quinines, polyphenolic, volatile oil, amino acids, organic acids, tannins, proteins, carbohydrates, phenols, starch, sugars, mucilage, bacosides a $\& b$, herpestine and Brahmin, coumarins. The abovediscussed plants were proved that they have Anti-microbial activity, anti-bacterial activity, anti-fungal, anti-oxidant, analgesic, anti-inflammatory activity, anti-diabetic, anticancer, anti-tussive, anti-tubercular, wound healing activity, hepatoprotective activity, CNS depressants, hypolipidemic activities.

\section{REFERENCES:}

1. Sandeep Dhankhar, Ramanjeet Kaur, S. Ruhil, M. Balhara, Seema Dhankhar and A.K. Chhillar, A review on Justicia adhatoda, a potential source of natural medicine, African journal of plant science, 2011; 5(11):620-627.

2. Rajesh Dabur, Amita Gupta, T K Mandal, Desh Deepak Singh, Vivek Bajpai, A M Gurav, and G S Lavekar, Antimicrobial Activity of Some Indian Medicinal Plants, African Journal of Traditional, Complementary and Alternative Medicines, 2007; 4(3):313-318.

3. Alka Sharma and Ashwani Kumar, Antimicrobial Activity of Justicia Adhatoda, World Journal of Pharmaceutical Research, 2016; 5(7):1332-1341.

4. Gupta Abhishek, Joshi Apurva, Joshi VK, Pharmacognostical Study of Justicia adhatoda Linn.Leaf, International Journal of Herbal Medicine, 2014; 1(6):01-04.

5. Joshi Apurva, Gupta Abhishek, Joshi VK, Pharmacognostical Study of Justicia adhatoda Linn.Leaf, International Journal of Herbal Medicine, 2014; 1(6):01-04.

6. FS Barreto, Eosousa, AR Campos, JGM Costa and FFG Rodrigues, Anti-bacterial activity of Lantana Camara and lantana montevidensis brig extract from Cariri-Ceara, Brazil, Journal of young pharmacists, 2010; 2(1):42-44.

7. Abeer M Haj Ali, Sanaa O. Yagoub, Anti-microbial activity of acacia leucophloea extracts against some bacteria isolated from clinical specimens, Journal of medicinal plants, 2007; 1(1):25-28.

8. Showkat Ahmad Ganie and Surendar sing Yadav. A Review of its Ethnobotany, Pharmacology, and Phytochemistry, Biomed Research International, 2014; 401213:12.

9. Kareem, S.O, Akpan. I and Ojo. O.P, Anti-microbial activities of calotropis procera on selected pathogenic microorganisms, African journal of biomedical research, 2008; 11:105-110.

10. Ghorpade D.S, Thakare P.V, Phytochemical screening and antimicrobial activity of chlorophytum species leaves of melghat region, International journal of pharmacognosy and phytochemical research, 2014; 6(1):141-145.

11. Digge V.G, Kuthar Sonali, Hogade Maheshwar G, Poul B.N and Jadge Dhanraj R, Screening of antibacterial activity of Aqeuos bark extract of bombax ceiba against some gram-positive and gram-negative bacteria, American journal of phytomedicine and clinical therapeutics, 2015; 3(7):551-555.
12. T.Ghosh, T.K.Maity, A.Bosel, G.K. Dash, M. Das, A study on antimicrobial activity of Bacopa monnieri Linn, Aerial parts, Journal of natural remedies, 2006; 6(2):170-173.

13. Govindappa M, Naga Sravya S, Poojashri M, Sadananda T. S, Chandrappa C.P, Gustavo Santoyo, Sharanappa P and Anil Kumar N.V, Anti-microbial, anti-oxidant and in vitro anti-inflammatory activity and phytochemical screening of water extract wedelia trilobata (L) Hitchc, Journal of medicinal plants research, 2011; 5(24):5718-5729.

14. U.C Bapat and D.R Mhapsekar, Study of anti-microbial activity and phytochemical evaluation of jatropha gossypifolia, International journal of pharmaceutical science and research, 2014; 5(11):4933-41.

15. G.Jayapriya and F. Gricilda Shoba, Phytochemical Analysis, Antimicrobial Efficacy and Determination of Bioactive Components from Leaves of Justicia Adhatoda (Linn), Asian Journal of Plant Science and Research, 2015; 5(2):43-51.

16. Eosousa, AR Campos, JGM Costa and FFG Rodrigues, Antibacterial activity of Lantana Camara and lantana montevidensis brig extract from cariri-Ceara, Brazil, Journal of young pharmacists, 2010; 2(1):42-44.

17. Mukesh Pote and Pradip Hirapure, Antimicrobial potential of acacia nilotica extracts on few dental pathogens, International journal of pharmaceutical sciences and research, 2017; 09759232:4756-4759.

18. Kareem, S.O, Akpan. I and Ojo. O.P, Anti-microbial activities of calotropis procera on selected pathogenic microorganisms, African journal of biomedical research, 2008; 11:105-110.

19. Ghorpade D.S, Thakare P.V, Phytochemical Screening and Antimicrobial Activity of Chlorophytum Species Leaves of Melghat Region, International Journal of Pharmacognosy and Phytochemical Research 2014; 6(1):141-145.

20. Kuthar Sonali, Hogade Maheshwar G, Poul B.N and Jadge Dhanraj $\mathrm{R}$, Screening of antibacterial activity of Aqeuos bark extract of bombax ceiba against some gram-positive and gram-negative bacteria, American journal of phytomedicine and clinical therapeutics, 2015; 3(7):551-555.

21. T.K.Maity, A.Bosel, G.K. Dash, M. Das, A study on anti-microbial activity of Bacopa monnieri Linn, Aerial parts, Journal of natural remedies, 2006; 6(2):170-173.

22. Nagamani JE, Vidya Sri D, Syeda hajira Banu, A study on Antioxidant and anti-microbial properties of bombax ceiba pentandra seed extracts, world journal of pharmacy and pharmaceutical sciences, 2014; 3(12):692-706.

23. Naga Sravya S, Poojashri M, Sadananda T. S, Chandrappa C.P, Gustavo Santoyo, Sharanappa P and Anil Kumar N.V, Antimicrobial, anti-oxidant and in vitro anti-inflammatory activity and phytochemical screening of water extract wedelia trilobata (L) Hitchc, Journal of medicinal plants research, 2011; 5(24):5718-5729.

24. U.C Bapat and D.R Mhapsekar, Study of anti-microbial activity and phytochemical evaluation of jatropha gossypifolia, International journal of pharmaceutical science and research, 2014; 5(11):4933-41.

25. Vidya Sri D, Syeda hajira Banu, A study on Anti-oxidant and antimicrobial properties of bombax ceiba pentandra seed extracts, world journal of pharmacy and pharmaceutical sciences, 2014; 3(12):692-706.

26. V. Duraipandiyan, N. A. AI-Dhabi, C. Balachandran, S. Ignacimuthu, C. Sankar, and K. Balakrishna, Antimicrobial, antioxidant, and Cytotoxic properties of Vasicine Acetate synthesized from Vasicine isolated from Adatoda vasica L., Bio Med Research International, 2015; 10-1155:727304.

27. Poojashri M, Sadananda T. S, Chandrappa C.P, Gustavo Santoyo, Sharanappa P and Anil Kumar N.V, Anti-microbial, anti-oxidant and in vitro anti-inflammatory activity and phytochemical screening of water extract wedelia trilobata (L) Hitchc, Journal of medicinal plants research, 2011; 5(24):5718-5729.

28. M Padmaja, M Sravanthi, K.P.J. Hemalatha, Evaluation of antioxidant activity of two Indian medicinal plants, Journal of phytology, 2011; 3(3):86-91. 